\title{
Out-Crossing Among Commercial Strains Of The Northern \\ Quahog, Mercenaria Mercenaria: Survival, Growth And Implications For Selective Breeding
}

\author{
MD Camara \\ Standish K. Allen Jr. \\ Virginia Institute of Marine Science \\ Ryan Carnegie \\ Virginia Institute of Marine Science \\ Kimberly S. Reece \\ Virginia Institute of Marine Science
}

Follow this and additional works at: https://scholarworks.wm.edu/vimsarticles

Part of the Marine Biology Commons

\section{Recommended Citation}

Camara, MD; Allen, Standish K. Jr.; Carnegie, Ryan; and Reece, Kimberly S., "Out-Crossing Among Commercial Strains Of The Northern Quahog, Mercenaria Mercenaria: Survival, Growth And Implications For Selective Breeding" (2006). VIMS Articles. 448.

https://scholarworks.wm.edu/vimsarticles/448

This Article is brought to you for free and open access by the Virginia Institute of Marine Science at W\&M ScholarWorks. It has been accepted for inclusion in VIMS Articles by an authorized administrator of W\&M ScholarWorks. For more information, please contact scholarworks@wm.edu. 


\title{
OUT-CROSSING AMONG COMMERCIAL STRAINS OF THE NORTHERN QUAHOG, MERCENARIA MERCENARIA: SURVIVAL, GROWTH AND IMPLICATIONS FOR SELECTIVE BREEDING
}

\author{
MARK D. CAMARA, ${ }^{1,2 *}$ STANDISH K. ALLEN, JR., ${ }^{1}$ RYAN B. CARNEGIE ${ }^{1}$ AND \\ KIMBERLY S. REECE ${ }^{1}$ \\ ${ }^{1}$ Virginia Institute of Marine Science, P.O. Box 1346, Gloucester Point, Virginia 23062; ${ }^{2}$ Current \\ address: USDA Agricultural Research Service, Hatfield Marine Science Center, 2030 SE Marine \\ Science Dr., Newport, Oregon 97365
}

\begin{abstract}
Because the accumulation of inbreeding within hatchery-propagated stocks of the hard clam, Mercenaria mercenaria (Linnaeus, 1758), could result in reduced growth and survival, we studied the potential for improving performance through out-crossing among existing hatchery strains. We produced all 10 possible out-crossed combinations among 5 strains of clams as well as all 5 pure parental strains simultaneously in the hatchery and measured their size at the time of metamorphosis (the spat stage) and at the end of a nursery period in mesh bags at a single field site (the seed stage). We then planted replicate plots of all fifteen strains at five field sites in Virginia, USA encompassing the range of salinity conditions used by commercial growers, and monitored growth and survival for two growing seasons. We found significant phenotypic differences among strains at the spat and seed stage, but different strains performed best at each stage. In the field we found significant site effects, strain effects and strain-by-site interactions, but there was no evidence of negative correlations in performance among sites indicating strong trade-offs that would be problematic for selective breeding. Three different linear contrasts designed to compare out-crossed and pure strains for each parental stock, test for nonadditive genetic effects within each pairing of different parental strains, and estimate the general combining ability of parental strains reveal a complex pattern. We found both inbreeding and out-breeding depression depending on the developmental stage of the clams and the parental strain examined. Within strain crosses generally produced larger spat but smaller seed. Out-crossed progeny were generally smaller at the spat stage than the average of their parental lines but larger at the seed stage. The two best performing parental strains had significant, positive, general combining abilities, whereas this measure was negative for the two worst parental strains. In the field, inbreeding depression was restricted to lines that showed poor pure strain performance, and these strains also showed poor general combining ability, whereas strains with good pure line performance showed out-breeding depression and good general combining ability. Only the poorest performing pure parental lines showed non-additive effects when we compared each out-crossed strain to the mean of its parental strains, suggesting that heterotic effects are unlikely to be useful for selective breeding. Finally, there were significant correlations between seed measurements and field performance indicating that it may be possible, in the context of selective breeding programs, to weed out inferior strains or families early in the life cycle.
\end{abstract}

KEY WORDS: Mercenaria mercenaria, hard clam, northern quahog, breeding, genetics, heterosis, inbreeding

\section{INTRODUCTION}

On the eastern coast of the United States, the hard shell clam or Northern quahog, Mercenaria mercenaria (L.), is the most valuable aquaculture product produced. Wild populations historically supported a large subsistence, commercial and recreational fishery, but harvests have recently declined in many areas-probably caused by problems with water quality and overharvesting. On the other hand, the aquaculture sector of the hard clam market has been growing rapidly for the last $10-15 \mathrm{y}$ and clams are now cultured from Massachusetts to Florida. USDA figures indicate that the economic value of the clam aquaculture market grew from approximately \$5 million in 1995 to approximately \$38 million in food products and $\$ 1.2$ million in seed clams in 1998 (Anonymous, 2000).

Despite the coast-wide economic importance of this species and the clam farming industry, there have been relatively few genetic studies of $M$. mercenaria, and selective breeding and domestication efforts have been largely limited to informal programs of mass selection conducted by commercial seed producers without rigorous genetic analysis (Gallivan \& Allen 2000). The few genetic data available, along with anecdotal information from growers and hatchery operators, indicate that traits of economic interest such as growth and survival are heritable in hard clams

\footnotetext{
*Corresponding author. E-mail: Mark.Camara@oregonstate.edu
}

(recently reviewed by Hilbish 2001). Chanley (1960) reported that selection was able to improve growth in a population started from just three crosses. Hadley et al. (1991) reported a wide range of heritability estimates for growth (0-0.43), and Rawson and Hilbish (1990) reported a heritability of 0.37 for growth during the first 6 mo postspawning. Commonly cultured strains differ markedly in susceptibility to QPX disease, indicating a high degree of genetic control over this trait as well (Ford et al. 2002, Ragone Calvo \& Burreson 2002, Ragone Calvo et al. 2003). In addition, some aspects of shell coloration appear to have a relatively simple genetic basis (Chanley 1960) All indications, therefore, are that domestication and selective breeding of hard clams could result in marked improvement of economically important characters.

Complicating matters for would-be shellfish breeders and commercial growers alike, however, is the finding that genotype by environment interactions for growth and survival are common in bivalves, including M. mercenaria (Hilbish et al. 1993, Newkirk 1978b, Rawson \& Hilbish 1990, Rawson \& Hilbish 1991). As a consequence, genotypes that perform well in one environment may perform poorly under different environmental conditions, and it is unclear whether "generalist" genotypes that perform well under a wide range of conditions, such as those found in Pacific oysters (Langdon et al. 2003), can be found or created in hard clams. In the extreme case, genotype by environment interactions can take the form of strong genetic trade-offs in performance among environments such that good performers in one environment are neces- 
sarily poor performers in others, and breeders may have no choice but to develop environment-specific selection lines.

In addition, common procedures in commercial hatcheries such as mass spawning with complete mixing of gametes for fertilization and/or mixing of groups produced through more controlled fertilization procedures combined with aggressive sieving and sorting during the early stages (i.e., larvae, spat and seed) are not conducive to either selective breeding or the conservation of genetic diversity (Dillon \& Manzi 1993, Hadley 1993, Newkirk 1978a). These practices contribute to high variance in the contributions of individual parents to the breeding population through either differential fertilization success, larval mortality, or fecundity and can lead to the rapid accumulation of inbreeding, genetic drift, and low effective population size as has been demonstrated in Pacific oysters (Hedgecock \& Sly 1990). Unfortunately, if the limited information available from other bivalve species can be extended to hard clams, even relatively low levels of inbreeding may result in substantial reductions in growth and survival (Evans et al. 2004). Commercial-scale hatcheries are typically equipped with a relatively small number of very large tanks for larval culture and thus are poorly equipped to prevent inbreeding beyond attempting to include many parents in the hopes that few are related, and balancing the genetic contributions of parents at the time of fertilization (M. Camara and S. Allen, pers. obs). Unfortunately, a recent study in Pacific oysters (Taris et al., 2006) found that in larval cultures consisting of a mixture of families, the relative contributions of the families could change rapidly, especially if the slow-growing larvae are culled through sieving. In addition, these strategies cannot ameliorate the effects of even infrequent population bottlenecks, and as a result, hatchery strains are likely to have lower genetic diversity and be more inbred than wild populations as has been found in unselected hatchery strains of the Suminoe oyster, Crassostrea ariakensis (Zhang et al. 2005) and strains of the Eastern oyster, Crassostrea virginica selected for disease resistance (Carlsson et al., in review, Hare et al. 2006) Thus, out-crossing among genetically distinct strains may lead to marked improvement in performance as has been demonstrated in other bivalve species (Hedgecock et al. 2004, Hedgecock et al. 1996).

As a first step toward designing and implementing a genetically rigorous domestication and selective breeding program for hard clams at the Aquaculture Genetics and Breeding Technology Center in Gloucester Point, Virginia, we evaluated the performance of five genetic strains that are used extensively by commercial clam growers in the midAtlantic region of the USA, both as withinstrain crosses and in all possible pairwise combinations. Though we have no pedigree information from which to estimate the levels of relatedness among the parents used in any of our crosses, individuals from the same strain are much more likely to be related to each other than individuals from different strains. As a matter of convenience, therefore, we will sometimes refer to the withincross strains as "pure strains" or "inbred strains" and the amongstrain crosses as "hybrids" or "outbred" lines. We deployed all 15 genetic groups across a range of environments chosen to represent the spectrum of conditions under which hard clam aquaculture is practiced in Virginia. This experimental design allowed us to make comparisons of the performance of pure strains to each other, of each pure strain to outcrosses with the other four pure strains, of outcrossed strains derived from different combinations of parental strains and of outcrossed strains to predictions based on additive inheritance from their parental strains. In addition, we were able to determine if these relationships were stable across varying environmental conditions. Finally, by collecting data on growth and survival at several stages in the life history, we could evaluate the strain-level correlations among characters and the stability of these correlations across environments, to address questions about whether performance in the field was predictable from data gathered in the hatchery or nursery phases of hard-clam culture.

\section{MATERIALS AND METHODS}

\section{Broodstock Sources}

Researchers in Virginia and New Jersey (Ford et al. 2002, Ragone Calvo \& Burreson 2002, Ragone Calvo et al. 2003) have found marked differences in QPX resistance among strains produced in different regions when planted in common garden experiments. Therefore we selected a similar array of stocks for our study. However, because these studies found that the Florida stock they tested was highly susceptible to QPX, and because this finding resulted in a ban on the importation of clam seed from states south of Virginia into Virginia waters (http://www.mrc.virginia .gov/regulations/fr754.shtm), we did not use a Florida strain. Clam stocks were obtained from Massachusetts (MA), New Jersey (NJ), and South Carolina (SC), and two from Virginia (KK and VA). All strains except for VA were obtained from commercial hatcheries. The VA strain was the product of early, but limited, domestication efforts at the Virginia Institute of Marine Science (VIMS) led by Michael Castagna.

\section{Spawning, Larval Culture and Field Nursery}

All parental animals were brought to the VIMS shellfish hatchery in Wachapreague, Virginia in March of 2000 and brought into reproductive condition by holding them in static tanks at $19^{\circ} \mathrm{C}$ to $23^{\circ} \mathrm{C}$, and feeding them with high concentrations of a mixed diet of 3 species of cultured algae (Isochrysis galbana, Tetraselmis chuii, and Chaetoceros neogracilis). Water was changed three times per week. A few animals were checked weekly for gonadal development and gamete maturity by opening their shells and examining gametes microscopically. Fertilization is external in $\mathbf{M}$. mercenaria, and females do not store sperm. Thus, to produce pairwise matings without contamination caused by having males and females in the same spawning raceway, we first determined the sex of individual animals by spawning all parents on 30 March 2001 using a combination fluctuating temperature (Hadley et al. 1997) and the addition of microwave-killed sperm to the spawning trays. We then marked each animal individually and recorded its gender. Males and females were subsequently reconditioned for spawning in separate tanks using the same methods as mentioned earlier. On May 17, 2001, we respawned males and females in separate raceways using the same techniques as mentioned earlier.

We first obtained gametes from each of the parents in separate containers. To accomplish this, at the first sign of spawning, individual parents were removed from the spawning raceway, rinsed several times with filtered seawater, and placed in individual beakers filled with filtered seawater where they continued to release gametes. Males that refused to release sperm were strip-spawned by opening their shells, lacerating the gonads with a scalpel, and rinsing sperm into beakers with filtered seawater. We then combined eggs and sperm to produce the desired crosses among individuals.

To ensure that all groups were as representative as possible of 
their parent strains, and that the initial contributions of parents were reasonably balanced, we attempted to produce 20 full-sib families nested within each pure strain and hybrid cross at the time of fertilization and combined them one hour later. Gametes from as many as 10 males and 10 females from each parental strain were collected individually as described above. The eggs from each female were divided into six equal aliquots: one aliquot for each of the four hybrid groups involving that stock and two aliquots for within-strain crosses. Each aliquot was fertilized with sperm from a different male from the appropriate strain to produce full-sib families. For the hybrid groups the different males from each of the two parental strains were randomly paired with an equal number females from the other strain. The outbred strains were thus represented by up to 20 full-sib families derived from a total of up to 40 parents. Half of these families paired males from one parental strain with females from a second strain, and half paired females from the first strain with males from the second. For the five pure strains, the crosses were slightly different. Because the number of parents within each strain was limited, we used each male and female as parents for two different full-sib families. That is, sperm from each of the males was used to fertilize aliquots of eggs from two different females. As a result, the up to 20 full-sib families within the five pure strain crosses are actually a mixture of full and half-sib families derived from of a total of up to 20 parents, each of which contributed to two single-pair crosses. After fertilization was complete, all of the families, representing each pure or hybrid strain, were pooled to form 15 groups representing all possible combinations of the five parental strains. For two of our parental strains, we were unable to spawn 20 parents. Specifically we used only eight males and eight females from the SC stock, and only five males and five females from the VA stock.

Each of the resulting 15 pooled cultures was then split into two $200 \mathrm{~L}$ static larval rearing tanks, each containing approximately 1.5 million fertilized eggs to ensure against the loss of cultures and to distribute each group across potential environmental gradients in the hatchery. Tanks were maintained at $25^{\circ} \mathrm{C}$ and the developing larvae were fed cultured Isochrysis galbana twice daily until metamorphosis.

After setting, seed from the two larval tanks for each cross were pooled, and we reared the juveniles first in downwellers and then in upwellers in an outdoor nursery system supplied with unfiltered seawater from the estuary at Wachapreague, VA. On July 20, 2001, when the seed clams had reached about 3-5 mm in shell length, they were transferred to fine mesh spat bags and deployed on the bottom of Cherrystone Creek, VA until October 10, 2001 when they had reached about $10 \mathrm{~mm}$ in shell length. At this point, the spat bags were retrieved and the animals from each group were divided into 15 aliquots of 1,250 animals each as estimated volumetrically based on group-specific determinations of volume/ count relationships. Poor survival to this point of the $\mathrm{VA} \times \mathrm{VA}$ line permitted only 9 aliquots.

\section{Field Sites and Grow-out}

We then deployed the animals at 5 field sites chosen to represent the range of conditions used by commercial clam growers in Virginia. Site locations are shown in Figure 1 and include two high salinity "sea-side" locations in estuaries on the eastern side of the Delmarva peninsula (Quinby and Wachapreague Inlet), two midsalinity sites in the lower Chesapeake Bay (Hungar's Creek and York River), and one low salinity site (North River). The two

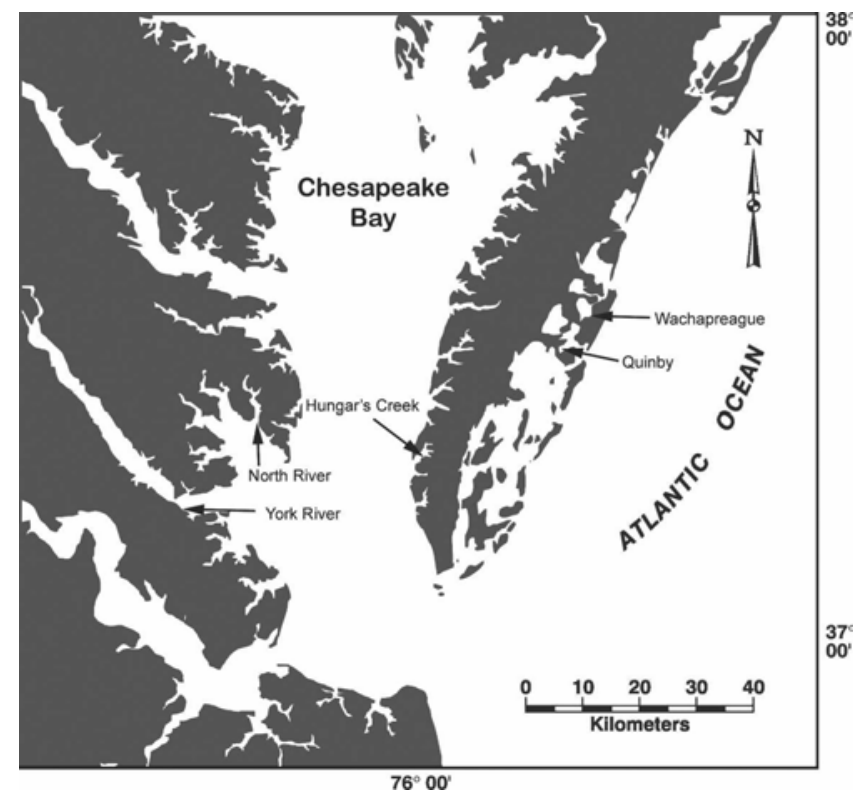

Figure 1. Map showing the locations of the five field sites in the Virginia portion of the Chesapeake Bay.

seaside sites experience high and stable salinity generally between $30 \%$ and $35 \%$ o. Salinity at the York River and Hungar's Creek sites varies seasonally from a low of about $12 \%$ in spring to nearly $25 \%$ in fall/winter, (http://www.vims.edu/data_archive/pier/figs/ others.html\#sal). The North River site is even more variable. Salinities at this site be as low as $0 \%$ after severe rain events and as high as $25 \%$ during extended droughts (K. Kurkowski, pers. comm.) At each site, we planted three replicate $1.52 \mathrm{~m} \times 1.52 \mathrm{~m}$ plots, each seeded with 1,250 animals that had been previously aliquoted with the exception of the pure VA line, which was not planted at the Hungar's Creek and North River sites. The Wachapreague site was planted on October 11, Quinby on October 12, North River on October 15 and Hungar's Creek and York River on October 16. The 45 plots at each site were arranged in a rectangular grid in a completely randomized design with plots separated by $0.91 \mathrm{~m}$. Each plot was covered with $6.5 \mathrm{~mm}$ plastic mesh to exclude predators, and the mesh was held in place by lengths of steel concrete reinforcement bar pressed into the substrate at the edges of the plots as is typical for commercial clam culture in Virginia. Plots were visited regularly to clean and maintain the predator exclusion nets, especially after damaging winter storms.

\section{Sample and Data Collection}

Samples of spat and seed were collected and preserved in ethanol at 2 stages in the process: (1) at the end of the nursery stage when the animals were transferred to fine mesh bags in the field, hereafter referred to as "spat" and (2) at the time of field planting, hereafter referred to as "seed." We measured the size of spat using image analysis. Approximately 100 randomly selected spat from each group were spread so that no two were in contact with each other in a clear plastic $150 \mathrm{~mm}$ diameter Petri dish placed on a light table and photographed using a digital camera mounted in a copy stand. To minimize parallax error, we positioned the camera approximately $60 \mathrm{~cm}$ above the dish and used the camera's zoom lens feature to fill the frame rather than placing the camera close 
to the dish. A ruler was included in the frame for calibration. Because of their bilaterally symmetric shape, all spat naturally assume the same position with one valve on the surface of the dish and the other facing the camera. We then used SigmaScan Pro image analysis software (SPSS Inc.) to quantify the area presented to the camera in $\mathrm{mm}^{2}$ by each of the spat in the digital image. For seed, we measured the shell length and shell width of a random sample of 20 animals from each group to the nearest $0.01 \mathrm{~mm}$ using digital calipers. Shell length was defined in this study as the longest dimension of the whole animal in anterior-posterior direction. Shell width was the longest dimension of the whole animal in the lateral dimension. We did not measure shell height (the longest dimension in the dorsal-ventral dimension).

Once the animals were planted in the field, we collected samples from the plots in the Autumn (Oct/Nov) of each year of the study (2002 and 2003). At each sampling date, we removed the net from each plot and removed 4 randomly located $10.2 \mathrm{~cm}$ diameter $\times 25 \mathrm{~cm}$ deep cores of sediment and all of the animals they contained. We sieved each of the cores in the field through 6.5 $\mathrm{mm}$ mesh and all live animals and empty shells were collected and counted to estimate the number of live clams in the plot. If we collected fewer than 20 animals in the core samples from any plot, we randomly collected more animals from that plot until we had collected 20 live animals for size measurements. We then brought all the live animals and shells back to the laboratory and measured their shell length and shell width to the nearest $0.01 \mathrm{~mm}$ using digital calipers.

\section{Statistical Analyses}

All statistical analyses were conducted using SAS version 8 (SAS, 2000). We first examined the frequency distributions and normal probability plots for all of our measurement data and found no marked departures from normality. We, therefore tested for overall differences among the genetic groups in the size of spat and seed using 1-way analysis of variance (ANOVA) with group as the single fixed factor with 15 levels and spat area, seed shell length and seed shell width as response variables. In these analyses, we used the among-individuals residual mean square as the error term in hypothesis tests because mixing the two larval cultures at metamorphosis made them effectively unreplicated.

We followed these ANOVAs with three sets of linear contrasts. The first set of contrasts compared the mean of each of the five pure strains to the pooled mean of the other four outbred strains in which it was represented as a parent. We refer to these as "pure versus hybrid" contrasts. The second set of contrasts ignored the pure lines altogether and for each of the five parental strains, compared the mean of the four hybrid strains to which it contributed to the mean of all 10 outbred lines. These contrasts estimate the average impact of each parental stock on the performance of hybrid progeny, typically referred to as "general combining ability" in analyses of within-population genetic variation (Falconer \& Mackay 1996). We refer to these contrasts as general combining ability contrasts even though our experiment involves crosses within and among outbred stocks rather than the more typical inbred lines or individual genotypes. The third set of contrasts tests for nonadditive contributions of the pure parental strains (i.e., dominance and epistasis [Falconer \& Mackay 1996]) in outcrossed hybrids by comparing each of the 10 outbred strains to the mean of the two inbred strains from which it was created. For brevity, we refer to these as "mid-parent" contrasts even though we did not collect any data on the actual parents but rather on the pure parental strains reared simultaneously.

Unlike the larval and nursery stages, each strain was planted in replicated plots at all sites in the field (with the previously noted exception that the VA pure line was not planted at two of the five sites). We therefore tested for differences among-sites and groups in survival (quantified as the number of live animals collected in the core samples) and both of the size-at-age measurements using 2-way ANOVA. The linear model included fixed effects of site and group, site-by-group interaction and, except for survival (which can only be measured on entire plots) a random effect of plot nested within site/group combinations. We also tested for differences between pure and hybrid strains within each of the sites using the same three sets of contrasts as earlier mentioned following separate 1-way analyses of variance for each site with group as the only factor.

To address whether significant site-by-group interactions take the form of strong trade-offs such that groups that perform well in one site tended to perform poorly in other sites, we tested all possible pair-wise correlations between the group means among sites with the expectation that trade-offs would manifest themselves as significant negative correlations.

Finally, because we wanted to determine if performance in the field was predictable from data collected in the hatchery or spat bag stage of culture, we tested for correlations between the group means for spat area and seed length at planting and the group means for survival and shell size measurements at each of the field sites.

\section{RESULTS}

\section{Hatchery/Nursery Characters: Spat and Seed Size}

There were significant overall differences among the 15 genetic groups in both the mean size of spat as measured by their areas and the mean size of seed as measured by shell length and shell width (Table 1a). Looking first at the spat area data, an examination of Figure 2a reveals that immediately post metamorphosis, the pure $\mathrm{NJ} \times \mathrm{NJ}$ line produced much larger spat than any of the other groups, that the $\mathrm{KK} \times \mathrm{KK}$ and $\mathrm{MA} \times \mathrm{MA}$ pure lines are larger (though less dramatically) than the others, and that all of the outcrossed lines that have the $\mathrm{KK}$ strain as one parent tend to be slightly larger than the remaining groups. The pure versus hybrid contrasts (Table 1b) show significant positive effects on spat area of crossing within strains (or conversely negative effects of outcrossing) for the KK, MA and NJ lines, no effect for the SC line, and a significant negative effect of inbreeding for the VA line. The general combining ability contrasts (Table 1c) show that the KKcontaining hybrid lines produce significantly larger spat than the average outcrossed strain, consistent with the observation earlier that lines with a KK parent are larger at the spat stage than others (Fig. 2a). In contrast, out-breeding the MA and VA lines to produce hybrids resulted in significantly smaller spat than the average outbred group as indicated by significant negative parameter estimates in the general combining ability contrasts, and hybrid lines that include the NJ or SC line as one parent do not differ from the mean of all outbred groups at the spat stage (Table 1c).

Because seed shell length and seed shell height were highly correlated $(r=0.995$, data not shown), and produced essentially identical statistical results, we present results for seed shell length only. There are significant differences among the 15 genetic groups in an overall analysis (Table 1a), but these effects are less 
TABLE 1.

Analysis of variance results for spat and seed measurements. A. Overall tests of heterogeneity of means of the $\mathbf{1 5}$ genetic groups produced. B. Parameter estimate and significance tests of linear contrasts comparing the mean of each pure strain to the mean of the four hybrid strains to which it contributed. Positive parameter estimates indicate that pure lines were superior to hybrid lines. $\mathrm{C}$.

Parameter estimates and significance tests of linear contrasts comparing the mean of the four hybrid groups that have the focal group as one parent to the mean of all 10 hybrid groups produced. Positive parameter estimates indicate that the focal line for a given contrast tended to produce superior progeny. D. Parameter estimates and significance tests of linear contrasts comparing each hybrid group to the mean of its two pure strain parental groups. Positive parameter estimates indicate that hybrid strains performed better than the average of the two parental stocks.

\begin{tabular}{|c|c|c|c|c|}
\hline \multicolumn{5}{|c|}{ A. Overall ANOVA results } \\
\hline & \multicolumn{2}{|c|}{ Spat area } & \multicolumn{2}{|c|}{ Seed length } \\
\hline & $\mathrm{F}$ & $P$ & $\mathrm{~F}$ & $P$ \\
\hline Group & 69.75 & $* * *$ & 24.54 & *: \\
\hline \multicolumn{5}{|c|}{ B. Pure vs. hybrid contrasts } \\
\hline & Parameter & $P$ & Parameter & $P$ \\
\hline \multicolumn{5}{|c|}{ Parent strain } \\
\hline KK & 1.39 & $* * *$ & -0.95 & \\
\hline MA & 2.62 & $* * *$ & -1.54 & \\
\hline NJ & 6.38 & $* * *$ & 0.06 & $\mathrm{~ns}$ \\
\hline $\mathrm{SC}$ & 0.19 & $\mathrm{~ns}$ & -0.72 & $*$ \\
\hline VA & -1.97 & $* * *$ & -2.95 & \\
\hline
\end{tabular}

C. General combining ability contrasts

$\begin{array}{crcr} & \text { Parameter } & P & \text { Parameter } \\ \text { Parent strain } & & & \\ \text { KK } & 0.89 & * * * & 0.32 \\ \text { MA } & -0.43 & * * * & -0.46 \\ \text { NJ } & 0.07 & n s & 0.16 \\ \text { SC } & -0.02 & n s & 0.60 \\ \text { VA } & -1.97 & * * * & -0.62\end{array}$

D. Mid-parent vs. out-crossed contrasts

\begin{tabular}{lrcrc} 
Hybrid & Parameter & $P$ & Parameter & $P$ \\
$\mathrm{KK} \times \mathrm{MA}$ & -3.55 & $* * *$ & 2.51 & $* * *$ \\
$\mathrm{KK} \times \mathrm{NJ}$ & -5.62 & $* * *$ & 1.08 & $\mathrm{~ns}$ \\
$\mathrm{KK} \times \mathrm{SC}$ & -0.31 & $\mathrm{~ns}$ & 1.80 & $* *$ \\
$\mathrm{KK} \times \mathrm{VA}$ & 1.22 & $\mathrm{~ns}$ & 5.18 & $* * *$ \\
$\mathrm{MA} \times \mathrm{NJ}$ & -8.21 & $* * *$ & 0.64 & $\mathrm{~ns}$ \\
$\mathrm{MA} \times \mathrm{SC}$ & -3.87 & $* * *$ & 4.16 & $* * *$ \\
$\mathrm{MA} \times \mathrm{VA}$ & -3.02 & $* * *$ & 1.10 & $\mathrm{~ns}$ \\
$\mathrm{NJ} \times \mathrm{SC}$ & -7.61 & $* * *$ & 2.37 & $* * *$ \\
$\mathrm{NJ} \times \mathrm{VA}$ & -5.95 & $* * *$ & 2.63 & $* * *$ \\
$\mathrm{SC} \times \mathrm{VA}$ & 2.51 & $* * *$ & 2.92 & $* * *$ \\
\hline
\end{tabular}

ns $=$ not significant, $*=P<0.05 ; * *=P<0.01 ; * * *=P<0.001$.

attributable to the differences seen for the NJ, KK and MA pure lines spat area data. Rather, the most obvious patterns are that all groups that have either a KK or SC parent tend to produce larger seed than those that do not (Fig. 2b). The general combining ability contrasts among outbred strains (Table 1c) confirm this. Seed from $\mathrm{KK}$ - and SC-containing hybrid lines were significantly larger than the average outbred strain, and MA- and VA-containing outbred lines were significantly smaller. Contrasts comparing the pure versus hybrid progeny of each parental strain (Table 1b) show significant inbreeding depression of seed shell length in the KK, MA,

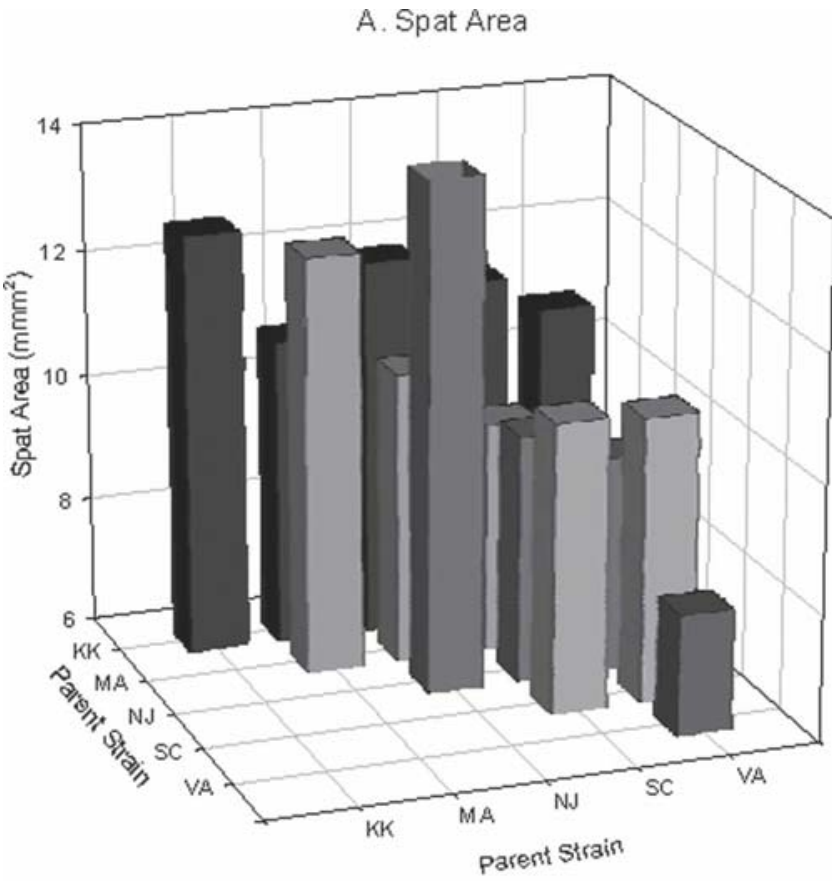

\section{B. Shell Length of Seed}

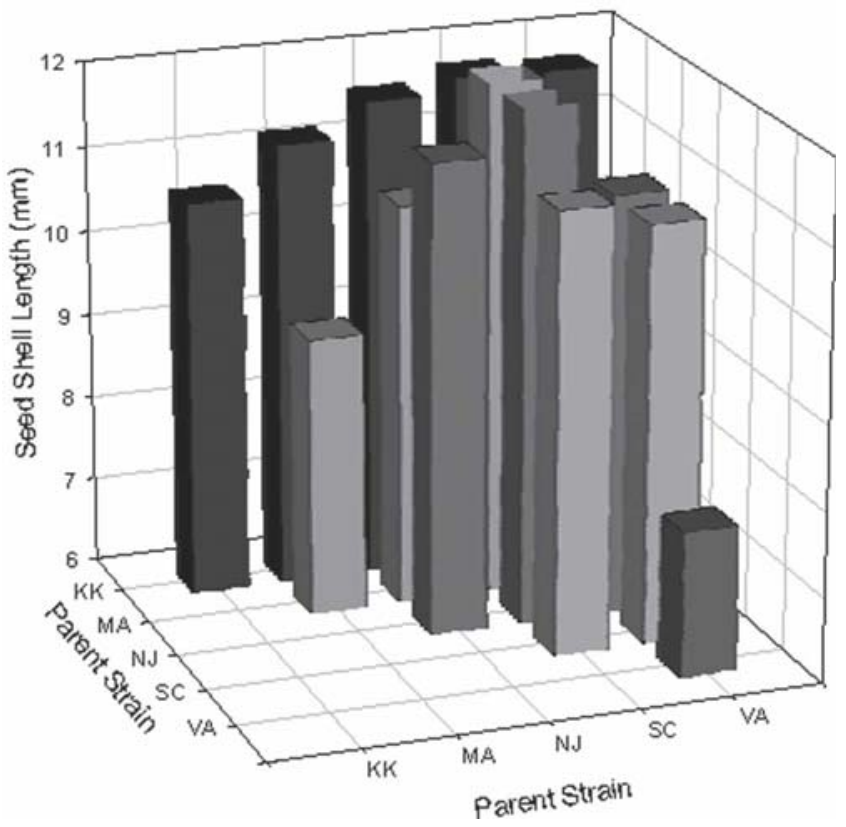

Figure 2. Size measurements for spat and seed. A. Spat area for all 15 possible combinations of the 5 parental stocks. B. Seed shell length.

VA and SC lines, but these effects are much stronger in the VA and MA lines than in the $\mathrm{K}$ and SC strains. There were no significant effects of inbreeding on seed size in the NJ line.

The midparent contrasts (Table 1d) for spat area show significant negative effects for 7 of the 10 hybrid lines indicating that out-crossed spat are typically smaller than the average of their parental stocks. There was also one significant positive effect and two of these contrasts were nonsignificant. For seed shell length, seven of the possible contrasts are significant. All of these significant tests have positive parameter estimates indicating that at the 
TABLE 2.

Overall analysis of variance results for field measurements in Autumn 2002 and Autumn 2003 testing for heterogeneity of means of the 15 genetic groups produced and group-by-site interactions.

\begin{tabular}{|c|c|c|c|c|c|c|c|c|}
\hline & \multicolumn{4}{|c|}{ Autumn 2002} & \multicolumn{4}{|c|}{ Autumn 2003} \\
\hline & \multicolumn{2}{|c|}{ \# Live } & \multicolumn{2}{|c|}{ Length } & \multicolumn{2}{|c|}{ \# Live } & \multicolumn{2}{|c|}{ Length } \\
\hline & $\mathbf{F}$ & $P$ & $\mathbf{F}$ & $P$ & $\mathbf{F}$ & $P$ & $\mathbf{F}$ & $P$ \\
\hline Site & 35.18 & $* * *$ & 142.04 & $* * *$ & 3.97 & $*$ & 63.01 & $* * *$ \\
\hline Group & 3.59 & $* * *$ & 32.49 & $* * *$ & 1.94 & $*$ & 22.62 & $* * *$ \\
\hline Site $*$ Group & 0.86 & ns & 1.44 & * & 1.01 & ns & 1.4 & ns \\
\hline Plot (Site * Group) & - & - & 3.74 & $* * *$ & - & - & 3.65 & $* * *$ \\
\hline
\end{tabular}

ns $=$ not significant, $*=P<0.05, * *=P<0.01, * * *=P<0.001$, $-=$ not testable.

seed stage, most hybrid crosses are larger than expected by additive contributions of the two parental strains.

\section{Field Characters: Size-at-Age and Survival}

The overall analyses of variance for the survival and size-at-age measurements (Table 2) reveal that mean survival and shell length in the field differed significantly among field sites and among genetic groups at the Autumn 2002 and Autumn 2003 samplings.
For shell length in Autumn 2002 there was also a significant interaction effect between site and group but not for survival in either year or shell length in 2003. An examination of the pattern of survival in the field among sites reveals that the site effects on survival in 2002 (Fig. 3) are largely caused by much higher survival at the Wachapreague site than all other sites and lower survival of all groups at the Hungar's Creek and Quinby sites, whereas by 2003 the number of survivors is highest at the Quinby site (Fig. 4). It should be noted, however, that these data have some limitations. Our cores samples, for example, captured more live animals in 2003 than in 2002 at the Quinby site. One possible explanation is that the soft, muddy bottom at the Quinby site caused us to under sample these plots in 2002 because the clams were deeper than our core samples. This is, however, very unlikely to have been a problem at other sites where the bottom was firm sand.

For shell length in the field (Fig. 5 and Fig. 6), the significant main effect of sites is largely driven by the larger size of animals at the York River site and smaller size in Hungar's Creek in 2002. In 2003, site effects are less dramatic, partly owing to the loss of the York River site to Hurricane Isabel, but animals at the Quinby, Wachapreague and Hungar's Creek sites are clearly larger overall than at North River.

Pure versus hybrid contrasts for each parental strain at each of the 5 sites (Table 3a) reveal mixed effects. The KK strain showed
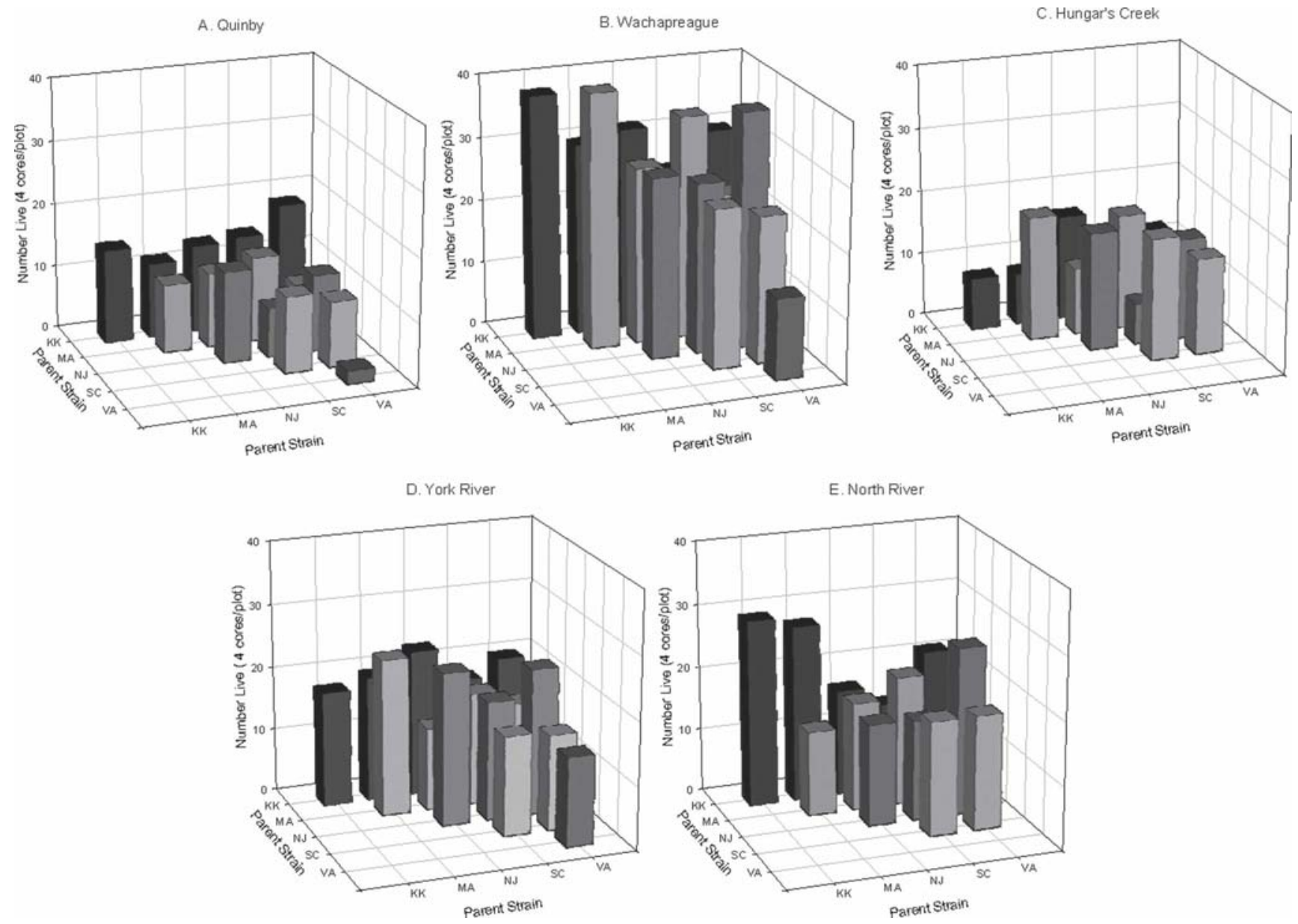

Figure 3. Survival at the Fall 2002 sampling date of all possible combinations of the 5 parental stocks at each of the 5 field sites as represented by the number of live animals collected in the four core samples. 

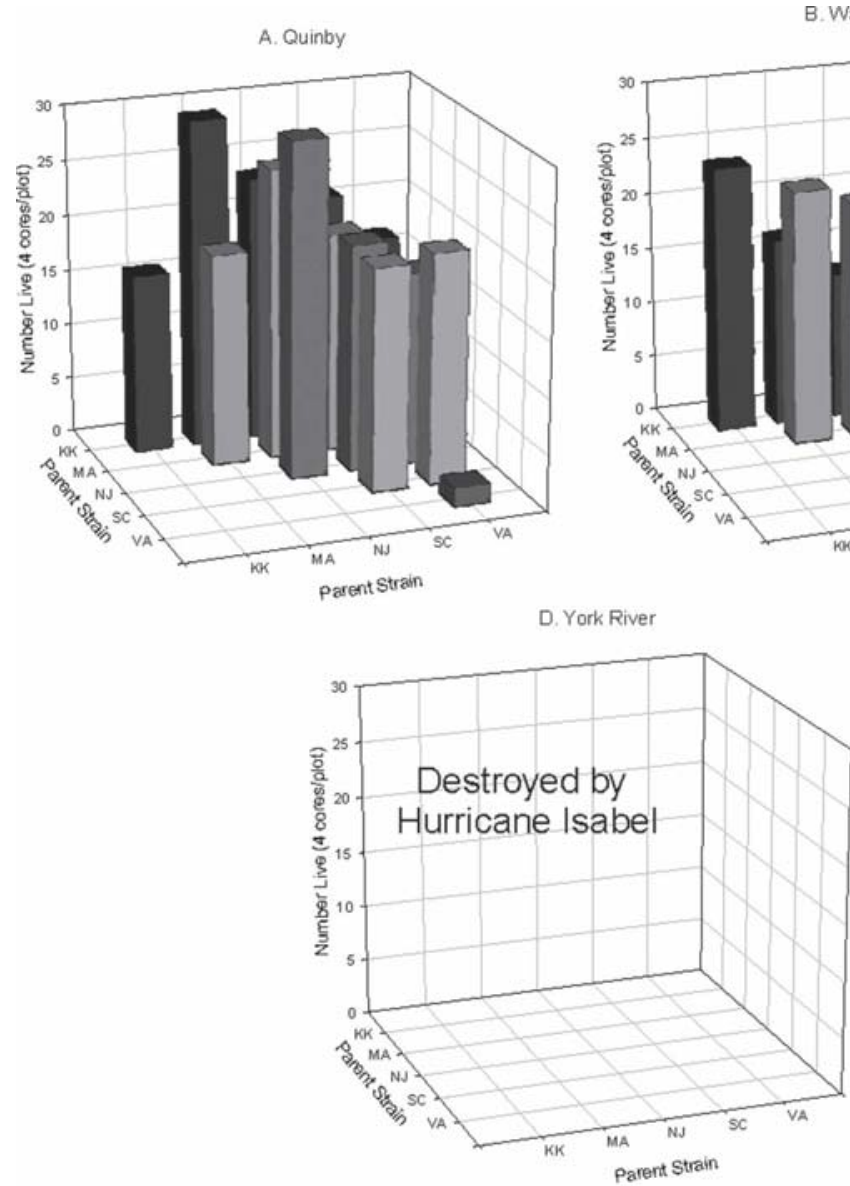

B. Wachapreague

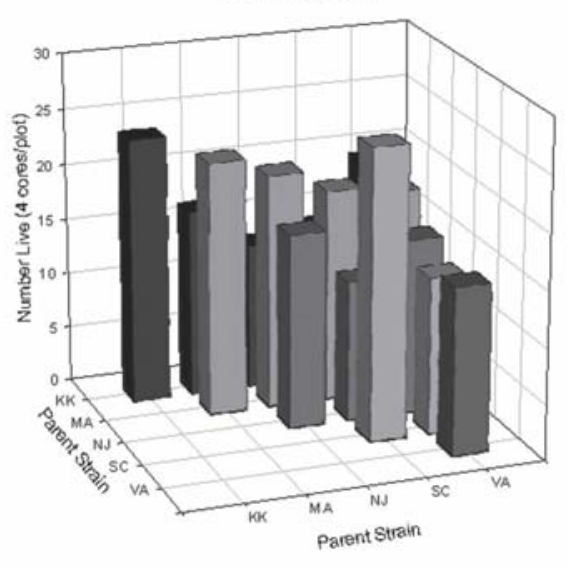

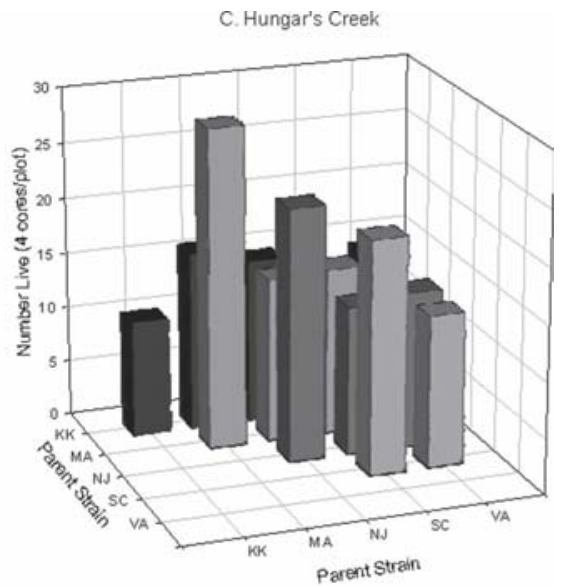

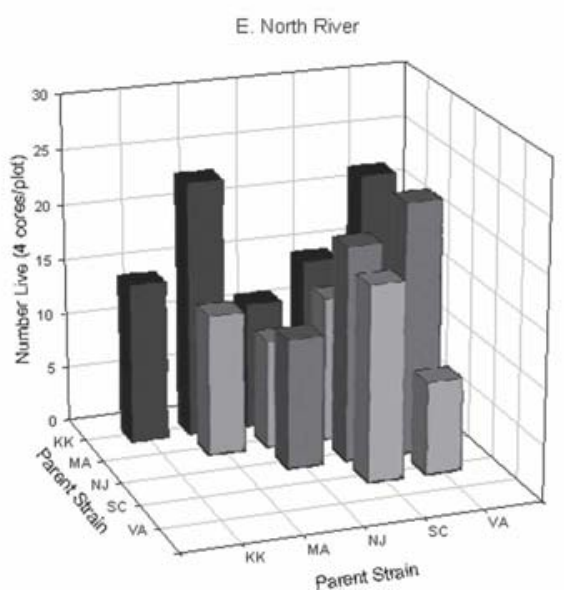

Figure 4. Survival at the Fall 2003 sampling date of all possible combinations of the 5 parental stocks at each of the 5 field sites as represented by the number of live animals collected in the four core samples collected.

no significant comparisons. In contrast, the MA line shows a wide array of effects caused by crossing within the strain. When crossed with itself, the MA line shows higher survival at the York River site and reduced shell length at all sites except for Hungar's Creek in 2002. In 2003, pure strains of the MA line produced significantly higher survival at the Hungar's Creek site accompanied by reduced shell length at all sites. The NJ line shows no significant effects of inbreeding on any of our measurements at any of the sites in either year. Pure SC stocks were significantly larger in 2003 at the North River site, but there were no other differences. The VA line showed the most dramatic effects of crossing withinstrain, with negative impacts at all sites where it was planted in both years except for survival in 2002 at the York River site and in 2003 at Wachapreague. All in all, the 2002 field data produced 10 significant pure versus hybrid contrasts out of a total of 46 possible tests, and of these 10 , only 1 is positive indicating better survival of the MA pure strain relative to its hybrids lines at the York River site and 9 are negative indicating inferior growth or survival in the pure MA and VA lines at multiple sites. In 2003, however, of the 36 possible comparisons (owing to the destruction of the York River site), 2 show significant positive effects of within-line crossing (for survival of the MA line at the Hungar's Creek site and shell length of the SC line at the North River), and 7 are negative. Of these 7 all are in the MA and VA lines and 6 indicate inferior growth of pure crosses.

Comparing general combining abilities reveals strong differ- ences in the pattern of significance among the parental lines (Table $3 b)$. Groups with one KK parent are generally not significantly different from the average outbred strain at any site except for enhanced survival at the Quinby site in 2002 (Note, however, that this is the site where survival estimates are most suspect because of possible limitations of our sampling technique in the muddy substrate). Stocks with one MA parent survive in numbers equal to the average hybrid strain in both years, but are smaller at all sites in 2002 and at the North River site only in 2003. The NJ stock shows no significant general combining ability for any of the traits we measured. The SC parental stock shows no general combining ability for survival, but outbred strains with one SC parent are larger at all sites in both years. Stocks containing the VA parental line had lower than average survival until 2003 at the Quinby site and were smaller than the average outbred strain in both years with the exception of the Wachapreague site in 2003.

The midparent contrasts, evaluated separately at each site also show mixed effects (Table 3c). For survival until Autumn 2002, only 4 of the possible 42 contrasts are significant, with 2 being negative and 2 positive. In the autumn of 2003, of the 28 estimable contrasts only 1 shows a significantly positive nonadditive effect on survival. Many more of these contrasts are significant for shell length, with 15 of 42 significant in 2002, and 5 significant in 2003. In 2002 and 2003, all of the significant contrasts for shell length are positive, indicating that when these contrasts are significant, hybrid progeny are larger than expected from additive contribu- 

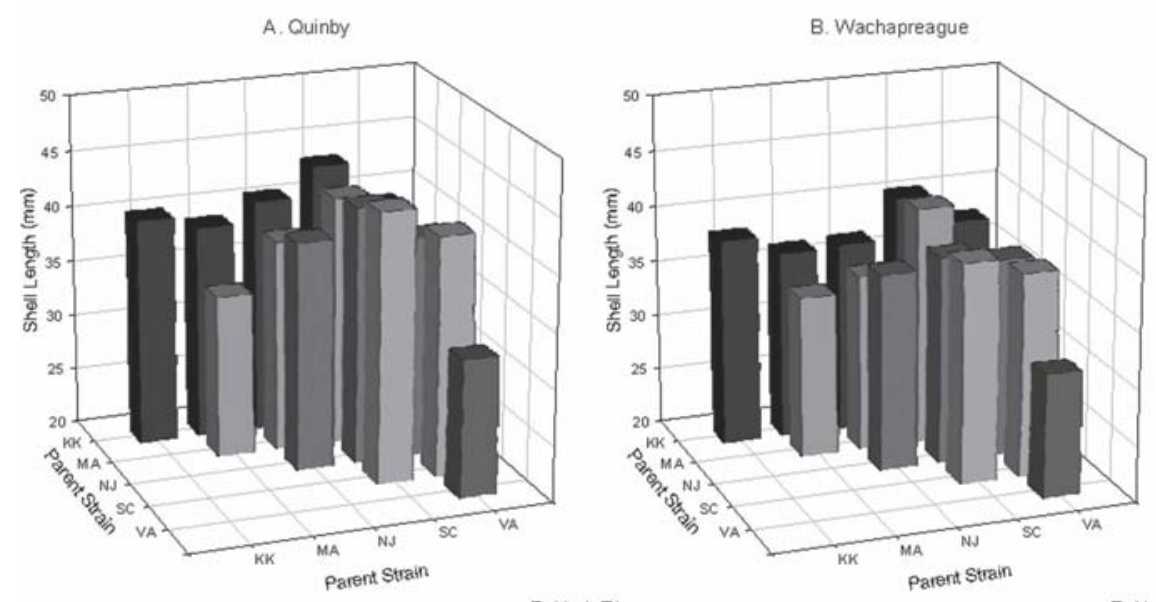

D. York River
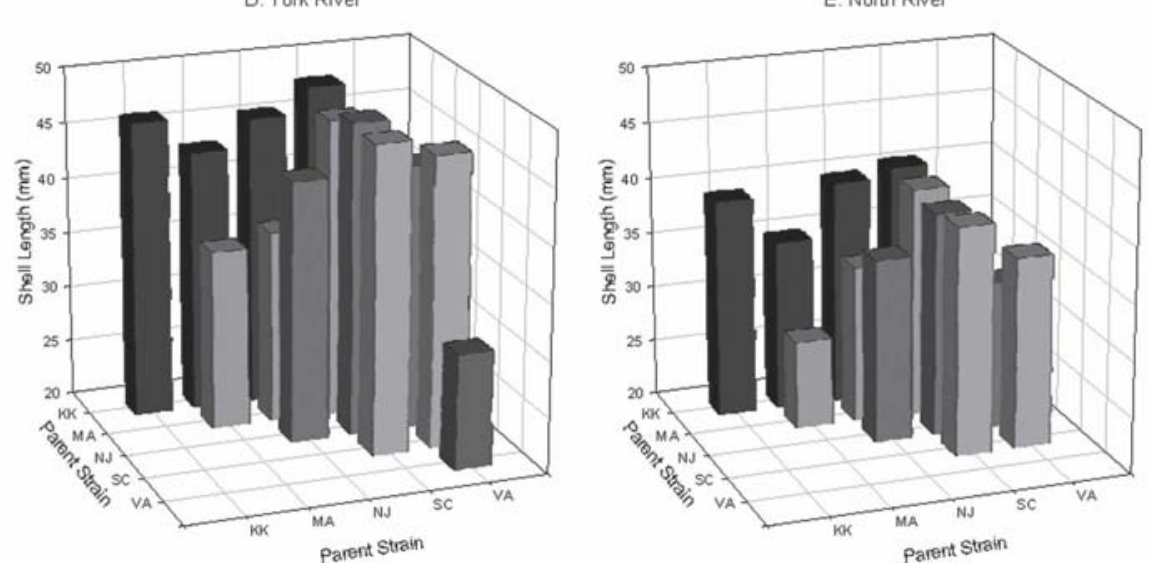

Figure 5. Shell length (largest dorso-ventral dimension) at the Fall 2002 sampling date of all possible combinations of the 5 parental stocks at each of the 5 field sites.

tions of parental strains. Further nearly all of the significant contrasts involve either the VA or MA parental lines as parents with the only exceptions being a significant positive effect on length for the $\mathrm{NJ} \times \mathrm{SC}$ cross at the North River site in both years.

Table 4 shows the group-level among-site correlations for survival and shell length in both Autumn 2002 and Autumn 2003. The survival data (Table 4a) produced only one statistically significant correlation, a positive relationship between survival at the Wachapreague and York River sites in 2002 (note, however, that the York River site was destroyed before the 2003 sampling period). Shell length (Table $4 \mathrm{~b}$ ) is positively correlated among sites for all pairwise combinations of field sites in both years, with correlation coefficients ranging from 0.7-0.95.

\section{Correlations Between Hatchery/Nursery and Field Measurements}

Table 5 contains the correlation matrices among the group means of the two adult characters we measured and between juvenile and adult characters. The hatchery traits (spat area and seed length) are significantly correlated with each other $(r=0.311)$. The correlation between adult shell length and the number of survivors is significant in $2003(\mathrm{r}=0.223)$, and at the Quinby site in both $2002(\mathrm{r}=0.525)$ and $2003(\mathrm{r}=0.557)$. There are, however, significant correlations between seed length, but not spat area, and both adult dimensions with correlation coefficients ranging from about 0.6 to nearly 0.9 .

\section{DISCUSSION}

This study reveals a number of patterns that should be taken into account by both commercial clam growers and by breeders seeking to develop domesticated and genetically improved hard clam strains. In the field, it is no surprise that site selection has strong influences on the average survival of the genetic strains we produced in this study (Fig. 3 and Fig. 4) and weaker effects on growth (Fig. 5 and Fig. 6). Both clam culturists and breeders should place a high priority on survival, with growers seeking sites that maximize survival and breeders seeking to improve and to stabilize survival across a range of conditions. This is consistent with the finding that in Pacific oysters survival is more genetically variable than growth (Ernande et al. 2004). Less pronounced, but also important are the consistently higher growth of specific strains regardless of the site at which they are planted. Despite statistically significant group by site interactions in the overall analyses, all of the groups that had one parent from either the KK or SC parental strains tended to be larger at all of our test sites, and there were no negative among-site correlations for survival or size-at-age measurements (Table 4). The implications of this for breeders are that if our results can be generalized beyond the small number of strains tested here, it may not be necessary to develop specialty strains for different environments because the same strains performed best in all environments despite significant genotype-byenvironment interactions. 

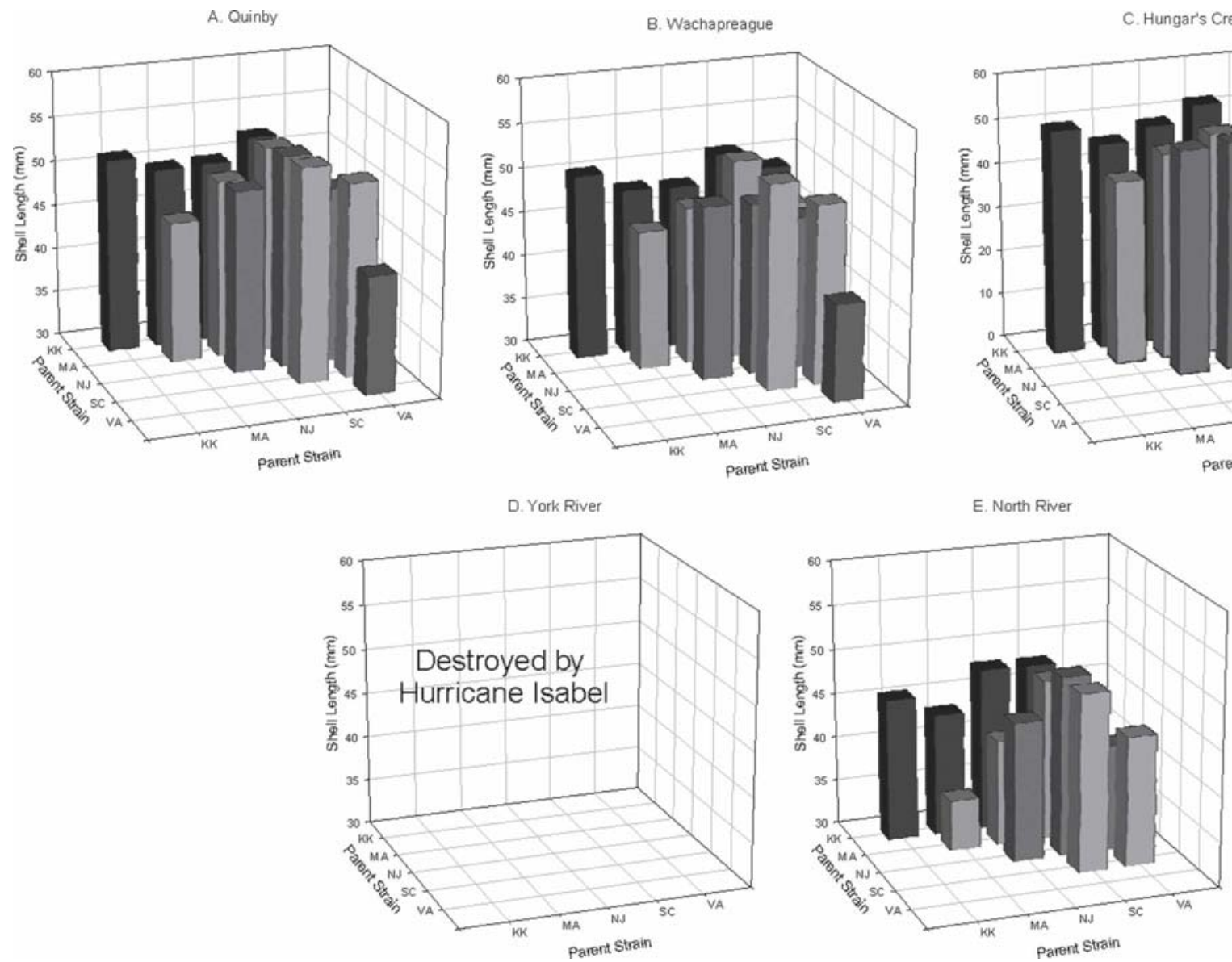

Figure 6. Shell length (largest dorso-ventral dimension) at the Fall 2003 sampling date of all possible combinations of the 5 parental stocks at each of the 5 field sites.

While we cannot be certain of the history of the stocks we used, all have been subjected to informal selection for a number of generations, and in some cases a combination of informal selection and inbreeding may have purged a substantial proportion of the deleterious alleles resulting in superior performing strains that can tolerate inbreeding. The implication here is that some low level of inbreeding may not be as detrimental as expected if it is accompanied by selection against deleterious alleles. The interplay between inbreeding and selection can be complex, especially in the presence of epistatis, genotype $\times$ environment interaction, or genetic correlations. While there is still a great deal of both theoretical and empirical work required in this area (see Chap. 10 in Lynch \& Walsh 2000), our data suggest that more precise studies of inbreeding and selection could be useful in designing an effective selective breeding program for hard clams.

In addition, breeders and broodstock managers must take into account their specific goals when making selection and management decisions. If, for example, the goal of a selective breeding program is to develop high-performance strains for use in aquaculture, our data indicate that some balanced between inbreeding and selection may purge deleterious alleles and produce high performing lines with little or no inbreeding depression. On the other hand, if the goal is to produce a genetically variable stock (e.g., for ecological restoration) then purging alleles that are deleterious under current conditions could have the undesirable effect of constraining the ability of restored populations to respond to changing conditions or novel pathogens.
Inbreeding effects also vary in the course of development. Crossing within strains, evaluated as the comparisons between pure and hybrid strains (Table 1b) generally has positive effects on spat area relative to among-strain crosses, with the exception of the VA stock, but negative effects later in development as measured by seed length. The same pattern is clear in the comparisons of hybrid lines to their midparent values (Table 1d), with hybrid progeny consistently smaller than the mean of the two parental lines as spat, but larger as seed. The most likely explanation for this pattern is that selection has been more intense and consistent for improved larval and nursery performance than for growth in the field under commercial conditions All clam hatcheries experience high levels of larval mortality during the larval phase and aggressively sieve their larval cultures to eliminate dead and slowgrowing larvae. In addition, the conditions in different hatcheries are likely to be quite similar because density, temperature, and food availability are relatively simple to control. In the field, however, mortality is typically lower and conditions are more variable from site to site. As a consequence, selection is likely to have been less intense and/or more variable in the field. Thus, selection in hatcheries is more likely to fix either favorable recessive genes or beneficial epistatic gene combinations and out-crossing is more likely to have detrimental impacts on hatchery performance.

In the field, the effects of crossing within parental strains are more complex. The significant comparisons between pure and hybrid groups that indicate negative effects that may be caused by inbreeding depression were concentrated in just two of the five 
TABLE 3.

Parameter estimates and significance tests of linear contrasts: A. Contrasts of the mean of each "pure strain" to the mean of the four hybrid strains to which it contributed. B. Contrasts of the mean of the four "hybrid" groups that have the focal group as one parent to the mean of all ten hybrid groups. C. Contrasts between each outcrossed hybrid group and the mean of its two pure strain parental groups.

A. Linear contrasts of pure vs. hybrid groups for each parent strain by site

Autumn 2002

\begin{tabular}{cclll}
\hline \# Live & & & \multicolumn{2}{c}{ Length } \\
Parameter & $P$ & & Parameter & $P$
\end{tabular}

Site

Parent Strain

KK

A

$$
\text { Hungar's Creek }
$$

North River

Quinby

Wachapreague

York River

Hungar's Creek

North River

Quinby

Wachapreague

York River

NJ

Hungar's Creek

North River

Quinby

Wachapreague

York River

SC

Hungar's Creek

North River

Quinby

Wachapreague

York River

VA

Hungar's Creek

North River

Quinby

Wachapreague

York River

\begin{tabular}{rr}
-3.67 & \\
9.50 & \\
0.08 & \\
9.33 & \\
-2.17 & \\
8.75 & \\
-4.50 & \\
-0.05 & \\
11.33 & \\
8.25 & \\
6.17 & \\
-2.91 & \\
3.08 & \\
-2.41 & \\
4.58 & \\
6.67 & \\
-1.08 & \\
0.58 & \\
-2.25 & \\
-1.58 & \\
- & \\
- & \\
-10.25 & \\
-15.33 & \\
-4.41 & \\
\hline
\end{tabular}

$\begin{array}{cr}\text { ns } & 0.79 \\ \mathrm{~ns} & 2.34 \\ \mathrm{~ns} & -0.34 \\ \mathrm{~ns} & 0.44 \\ \mathrm{~ns} & 1.69 \\ \mathrm{~ns} & -3.01 \\ \mathrm{~ns} & -7.02 \\ \mathrm{~ns} & -4.79 \\ \mathrm{~ns} & -2.50 \\ * & -5.79 \\ \mathrm{~ns} & -0.47 \\ \mathrm{~ns} & -0.55 \\ \mathrm{~ns} & -0.13 \\ \mathrm{~ns} & 0.42 \\ \mathrm{~ns} & -0.20 \\ \mathrm{~ns} & 0.63 \\ \mathrm{~ns} & 1.30 \\ \mathrm{~ns} & 1.66 \\ \mathrm{~ns} & -0.04 \\ \mathrm{~ns} & 0.39 \\ - & - \\ - & - \\ * * & -7.40 \\ * & -5.97 \\ \mathrm{~ns} & -12.58 \\ & \end{array}$

\section{ns}

ns

ns

ns

ns

$\mathrm{ns}$

$* * *$

$* * *$

*

***

ns

ns

ns

ns

ns

ns

ns

ns

ns

ns

-

-

$* * *$

$* * *$

B. Linear contrasts for general combining ability of each parent strain by site

Autumn 2002

\begin{tabular}{|c|c|c|c|c|c|c|c|c|c|}
\hline & & \multicolumn{4}{|c|}{ Autumn 2002} & \multicolumn{4}{|c|}{ Autumn 2003} \\
\hline & & \multicolumn{2}{|c|}{ \# Live } & \multicolumn{2}{|c|}{ Length } & \multicolumn{2}{|c|}{ \# Live } & \multicolumn{2}{|c|}{ Length } \\
\hline & & Parameter & $\boldsymbol{P}$ & Parameter & $P$ & Parameter & $P$ & Parameter & $P$ \\
\hline \multirow{6}{*}{$\begin{array}{c}\text { Parent Strain } \\
\text { KK }\end{array}$} & Site & & & & & & & & \\
\hline & Hungar's Creek & -0.13 & ns & 0.21 & ns & 0.38 & $\mathrm{~ns}$ & -0.73 & ns \\
\hline & North River & 1.53 & ns & 0.84 & ns & 2.68 & ns & 0.07 & ns \\
\hline & Quinby & 2.45 & $*$ & 0.19 & ns & 2.27 & ns & -0.18 & ns \\
\hline & Wachapreague & 0.27 & ns & 0.23 & ns & -0.06 & ns & 0.36 & ns \\
\hline & York River & 1.83 & ns & 0.81 & ns & - & - & - & - \\
\hline \multirow[t]{5}{*}{ MA } & Hungar's Creek & -1.21 & ns & -2.53 & $* *$ & -0.03 & ns & -1.16 & ns \\
\hline & North River & -0.47 & ns & -1.41 & $*$ & -1.98 & ns & -1.52 & $* *$ \\
\hline & Quinby & -0.97 & ns & -1.18 & $* *$ & 0.77 & ns & -0.68 & ns \\
\hline & Wachapreague & -0.07 & ns & -0.81 & $*$ & 2.38 & ns & -0.26 & ns \\
\hline & York River & -1.91 & ns & -2.29 & $* * *$ & - & - & - & - \\
\hline \multirow[t]{5}{*}{$\mathrm{NJ}$} & Hungar's Creek & 0.37 & ns & 1.42 & ns & 0.97 & ns & 1.04 & ns \\
\hline & North River & -0.62 & ns & 0.05 & ns & 0.68 & ns & 0.68 & ns \\
\hline & Quinby & -0.88 & ns & 0.08 & ns & 1.27 & ns & 0.13 & ns \\
\hline & Wachapreague & 2.17 & ns & -0.55 & ns & -0.82 & ns & -1.02 & ns \\
\hline & York River & 1.08 & ns & -0.38 & ns & - & - & - & - \\
\hline \multirow[t]{5}{*}{$\mathrm{SC}$} & Hungar's Creek & 0.53 & ns & 2.81 & $* *$ & -0.37 & ns & 1.78 & $*$ \\
\hline & North River & -1.38 & ns & 2.73 & $* * *$ & -1.23 & ns & 2.91 & $* * *$ \\
\hline & Quinby & -0.71 & ns & 2.00 & $* * *$ & -0.07 & ns & 2.08 & $* * *$ \\
\hline & Wachapreague & -1.48 & ns & 1.89 & $* * *$ & -1.49 & ns & 1.62 & $* *$ \\
\hline & York River & -1.08 & ns & 3.11 & $* * *$ & - & - & - & - \\
\hline \multirow[t]{3}{*}{ VA } & Hungar's Creek & 0.45 & ns & -1.92 & $*$ & -0.95 & ns & -2.39 & $*$ \\
\hline & North River & -0.30 & ns & -2.70 & $* * *$ & -0.15 & ns & -2.80 & $* * *$ \\
\hline & Quinby & -0.12 & ns & -1.10 & $* *$ & -4.23 & $*$ & -1.35 & $* * *$ \\
\hline
\end{tabular}

Autumn 2003

\begin{tabular}{lllll}
\multicolumn{3}{c}{ Autumn 2003} \\
\hline \# Live & & & \multicolumn{2}{c}{ Length } \\
\cline { 5 - 6 } Parameter & $P$ & & Parameter & $P$ \\
\hline
\end{tabular}

-3.25
-3.41
-6.83
7.88
-
15.50
-0.41
-2.33
3.91
-
8.50
-4.08
8.17
1.79
-
8.17
3.83
-0.50
11.13
-
-
-
-14.67
-1.88
-

\begin{tabular}{|c|c|c|}
\hline ns & 1.79 & ns \\
\hline ns & 0.50 & ns \\
\hline ns & 1.23 & ns \\
\hline ns & 1.28 & ns \\
\hline- & - & - \\
\hline$*$ & -5.64 & $*$ \\
\hline ns & -7.55 & $* * *$ \\
\hline ns & -4.17 & $* * *$ \\
\hline ns & -3.23 & $*$ \\
\hline- & - & - \\
\hline ns & 1.15 & ns \\
\hline ns & 0.10 & $\mathrm{~ns}$ \\
\hline ns & -0.42 & ns \\
\hline ns & 1.79 & ns \\
\hline- & - & - \\
\hline ns & 2.00 & ns \\
\hline ns & 2.23 & $*$ \\
\hline ns & 1.25 & ns \\
\hline ns & 2.29 & ns \\
\hline- & - & - \\
\hline- & - & - \\
\hline- & - & - \\
\hline$* *$ & -4.72 & $*$ \\
\hline ns & -7.42 & $* *$ \\
\hline- & - & - \\
\hline
\end{tabular}

Autumn 2003 
TABLE 3.

continued

\begin{tabular}{|c|c|c|c|c|c|c|c|c|}
\hline & \multicolumn{4}{|c|}{ Autumn 2002} & \multicolumn{4}{|c|}{ Autumn 2003} \\
\hline & \multicolumn{2}{|c|}{ \# Live } & \multicolumn{2}{|c|}{ Length } & \multicolumn{2}{|c|}{ \# Live } & \multicolumn{2}{|c|}{ Length } \\
\hline & Parameter & $P$ & Parameter & $P$ & Parameter & $P$ & Parameter & $P$ \\
\hline Wachapreague & -0.73 & ns & -0.76 & $*$ & 0.01 & ns & -0.68 & $\mathrm{~ns}$ \\
\hline York River & 0.08 & ns & -1.24 & $*$ & - & - & - & - \\
\hline
\end{tabular}

C. Linear contrasts of mid-parent vs. hybrid

Autumn 2002

Autumn 2003

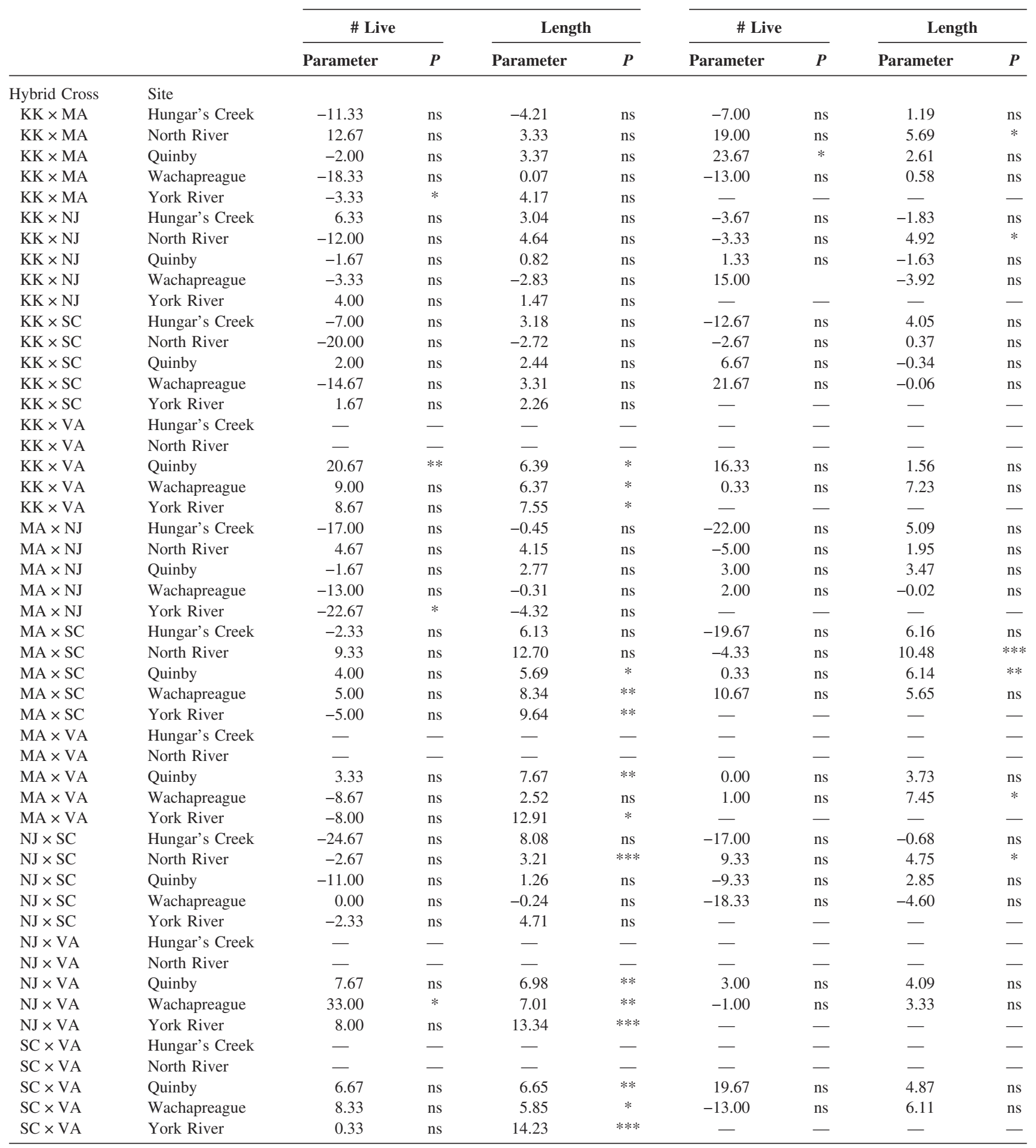

ns $=$ not significant, $*=P<0.05, * *=P<0.01, * * *=P<0.001,-=$ not testable. 
TABLE 4.

Pairwise correlation coefficients and significance tests among the group means at the five field sites. A. Survival as indicated by the total number of live animals collected in the core samples. B. Shell length. C. Shell width. Field data from the Autumn 2002 samples are below the diagonal and the values above the diagonal represent data from Autumn 2003.

\begin{tabular}{|c|c|c|c|c|c|}
\hline \multicolumn{6}{|c|}{ A. Survival } \\
\hline & & Hungar's Creek & North River & Quinby & Wachapreague \\
\hline \multirow[t]{2}{*}{ Hungar's Creek } & $\mathrm{r}$ & & 0.106 & 0.422 & 0.359 \\
\hline & $P$ & & ns & ns & ns \\
\hline \multirow[t]{2}{*}{ North River } & $\mathrm{r}$ & -0.024 & & -0.055 & -0.026 \\
\hline & $P$ & ns & & ns & ns \\
\hline \multirow[t]{2}{*}{ Quinby } & $\mathrm{r}$ & 0.228 & 0.414 & & -0.259 \\
\hline & $P$ & $\mathrm{~ns}$ & ns & & ns \\
\hline \multirow{2}{*}{ Wachapreague } & $\mathrm{r}$ & 0.380 & 0.434 & 0.487 & \\
\hline & $P$ & ns & ns & ns & \\
\hline \multirow[t]{2}{*}{ York River } & $\mathrm{r}$ & 0.397 & 0.009 & 0.413 & 0.707 \\
\hline & $P$ & ns & ns & ns & $* *$ \\
\hline \multicolumn{6}{|c|}{ B. Shell Length } \\
\hline & & Hungar's Creek & North River & Quinby & Wachapreague \\
\hline \multirow[t]{2}{*}{ Hungar's Creek } & $\mathrm{r}$ & & 0.838 & 0.802 & 0.688 \\
\hline & $P$ & & $* *$ & $* *$ & $*$ \\
\hline \multirow[t]{2}{*}{ North River } & $\mathrm{r}$ & 0.877 & & 0.895 & 0.705 \\
\hline & $P$ & $* * *$ & & $* * *$ & $* *$ \\
\hline \multirow[t]{2}{*}{ Quinby } & $\mathrm{r}$ & 0.921 & 0.912 & & 0.868 \\
\hline & $P$ & $* * *$ & $* * *$ & & $* * *$ \\
\hline \multirow{2}{*}{ Wachapreague } & $\mathrm{r}$ & 0.807 & 0.837 & 0.900 & \\
\hline & $P$ & $* * *$ & $* * *$ & $* * *$ & \\
\hline \multirow[t]{2}{*}{ York River } & $\mathrm{r}$ & 0.921 & 0.894 & 0.954 & 0.918 \\
\hline & $P$ & $* * *$ & $* * *$ & $* * *$ & $* * *$ \\
\hline
\end{tabular}

$\mathrm{ns}=$ not significant, $*=P<0.05, * *=P<0.01, * * *=P<0.001$.

parent strains that we tested - the MA and VA lines, both of which also showed large negative effects for general combining ability. The few positive effects of crossing within strains occurred in lines that also showed better overall performance (KK and SC), indicated by positive general combining ability. Hence, at least in this first hybrid generation, there is an association between the ability of a line to raise the mean growth of any group to which it contributes genetically and the absence of negative effects of crossing within that line. Conversely lines with negative general combining ability for growth also show inbreeding depression as pure strains relative to hybrid lines.

Our data also provide evidence of nonadditive effects of outcrossing in some of our hybrid crosses. As for pure versus hybrid contrasts, midparent contrasts are significant mainly for crosses involving two of the five parental strains, MA and VA. Keeping in mind that these two lines also show the most severe negative impacts of within-line crossing, as indicated by the pure versus hybrid contrasts as well as negative effects in the general combining ability contrasts, the positive nonadditive effects of outcrossing for these strains are attributable less to the superiority of hybrids, than to the poor performance of these two pure lines. That is, whereas hybrid crosses involving the MA and VA line are likely to exceed expectations based on the mean of their parental lines, these crosses are still inferior to hybrid crosses among other parental strains.

Our analysis of midparent comparisons in the hatchery and in the field, however, cannot determine whether they are the result of dominance or epistastis. Under the dominance hypothesis, hybrid crosses involving the poorest pure lines would perform better than the mean of their parental strains because of dominance of the alleles from the other (better) parent. Alternatively, to the degree to which the parental lines are homozygous at loci involved in epistatic complexes, this first generation of hybrid progeny would be expected to inherit entire gene complexes from their parents; and we would expect, therefore, that out-crossing of the poorest pure strains would also tend to enhance the performance of $F_{1}$ progeny by increasing the probability that they possess alleles that interact favorably. Only in the second generation posthybridization would we expect such fixed complexes, if they exist, to be disrupted by recombination (Falconer \& Mackay 1996, Lynch \& Walsh 1998). It is important, however to note that these nonadditive effects are restricted to the poorest performing parental lines and that there was little indication of nonadditive gene action in line crosses among the better parental lines. Thus, selective breeding and domestication efforts that emphasize selection on additive genetic variance should be effective, and our data provide no reason to believe that more complicated breeding schemes designed to use nonadditive heterotic effects, whatever the mechanism, would be advantageous over the judicious selection or construction of a base population with low inbreeding depression.

Further, the data presented here suggest that the beneficial effects of out-crossing we observed are not likely to be the result of heterozygosity per se. If that were the case, we would have expected that out-crossing would have improved performance in all 
TABLE 5.

Pairwise correlation coefficients and significance tests among the group means of three adult characters (shell length, width and number of survivors), between these characters and two of the characters measured in the hatchery and nursery (shell length at the seed stage and the area of spat) and between the spat and seed measurements (this reported only once below the diagonal).

A. Pooling all 5 of the field sites. B. For each site separately.

Field data from the Autumn 2002 samples are below the

diagonal and the values above the diagonal represent data from Autumn 2003.

\begin{tabular}{lccccc}
\hline \hline \multicolumn{5}{c}{ A. Sites Pooled } \\
\hline & & $\begin{array}{c}\text { Shell } \\
\text { Length }\end{array}$ & $\begin{array}{c}\text { Number } \\
\text { Live }\end{array}$ & $\begin{array}{c}\text { Seed } \\
\text { Length }\end{array}$ & $\begin{array}{c}\text { Spat } \\
\text { Area }\end{array}$ \\
\hline Shell length & $\mathrm{r}$ & - & 0.309 & 0.613 & 0.122 \\
& $P$ & - & $*$ & $* * *$ & $\mathrm{~ns}$ \\
Number live & $\mathrm{r}$ & 0.16 & - & 0.223 & 0.298 \\
& $P$ & $\mathrm{~ns}$ & - & $*$ & $*$ \\
Seed length & $\mathrm{r}$ & 0.546 & 0.184 & - & - \\
& $P$ & $* * *$ & $\mathrm{~ns}$ & - & - \\
Spat area & $\mathrm{r}$ & 0.1 & 0.212 & 0.311 & - \\
& $P$ & $\mathrm{~ns}$ & $\mathrm{~ns}$ & $* *$ & - \\
\hline
\end{tabular}

\section{B. By Site}

\begin{tabular}{|c|c|c|c|c|c|}
\hline Hungar's C & & $\begin{array}{l}\text { Shell } \\
\text { Length }\end{array}$ & $\begin{array}{l}\text { Number } \\
\text { Live }\end{array}$ & $\begin{array}{c}\text { Seed } \\
\text { Length }\end{array}$ & $\begin{array}{l}\text { Spat } \\
\text { Area }\end{array}$ \\
\hline Shell length & $\mathrm{r}$ & - & -0.216 & 0.728 & 0.199 \\
\hline & $P$ & - & $\mathrm{ns}$ & ** & ns \\
\hline Number live & $\mathrm{r}$ & 0.05 & - & -0.128 & 0.518 \\
\hline & $P$ & $\mathrm{~ns}$ & - & $\mathrm{ns}$ & ns \\
\hline Seed length & $\mathrm{r}$ & 0.784 & 0.045 & - & - \\
\hline & $P$ & $* * *$ & ns & - & - \\
\hline Spat area & $\mathrm{r}$ & 0.081 & 0.356 & - & - \\
\hline & $P$ & ns & ns & - & - \\
\hline North Riv & & $\begin{array}{c}\text { Shell } \\
\text { Length }\end{array}$ & $\begin{array}{c}\text { Number } \\
\text { Live }\end{array}$ & $\begin{array}{c}\text { Seed } \\
\text { Length }\end{array}$ & $\begin{array}{l}\text { Spat } \\
\text { Area }\end{array}$ \\
\hline Shell length & $\mathrm{r}$ & - & 0.157 & 0.799 & 0.04 \\
\hline & $P$ & - & ns & $* *$ & ns \\
\hline Shell width & $\mathrm{r}$ & 0.993 & 0.166 & 0.78 & 0.031 \\
\hline & $P$ & $* * *$ & ns & $* * *$ & ns \\
\hline Number live & $\mathrm{r}$ & 0.265 & - & 0.43 & -0.148 \\
\hline & $P$ & $\mathrm{~ns}$ & - & $\mathrm{ns}$ & ns \\
\hline Seed length & $\mathrm{r}$ & 0.799 & 0.309 & - & - \\
\hline & $P$ & $* * *$ & $\mathrm{~ns}$ & - & - \\
\hline Spat area & $\mathrm{r}$ & 0.068 & 0.037 & - & - \\
\hline & $P$ & $\mathrm{~ns}$ & ns & - & - \\
\hline Quinby & & $\begin{array}{l}\text { Shell } \\
\text { Length }\end{array}$ & $\begin{array}{l}\text { Number } \\
\text { Live }\end{array}$ & $\begin{array}{c}\text { Seed } \\
\text { Length }\end{array}$ & $\begin{array}{l}\text { Spat } \\
\text { Area }\end{array}$ \\
\hline Shell length & $\mathrm{r}$ & - & 0.557 & 0.859 & 0.204 \\
\hline & $P$ & - & * & $* * *$ & ns \\
\hline Number live & $\mathrm{r}$ & 0.525 & - & 0.686 & 0.644 \\
\hline & $P$ & $*$ & - & $* *$ & $*$ \\
\hline Seed length & $\mathrm{r}$ & 0.872 & 0.662 & - & - \\
\hline & $P$ & $* * *$ & $* *$ & - & - \\
\hline Spat area & $\mathrm{r}$ & 0.207 & 0.549 & - & - \\
\hline & $P$ & ns & $*$ & - & - \\
\hline
\end{tabular}

continued on next column
TABLE 5.

continued

\begin{tabular}{cccccc}
\hline \hline Wachapreague & $\begin{array}{c}\text { Shell } \\
\text { Length }\end{array}$ & $\begin{array}{c}\text { Number } \\
\text { Live }\end{array}$ & $\begin{array}{c}\text { Seed } \\
\text { Length }\end{array}$ & $\begin{array}{c}\text { Spat } \\
\text { Area }\end{array}$ \\
\hline Shell length & $\mathrm{r}$ & - & 0.243 & 0.796 & 0.305 \\
& $P$ & - & $\mathrm{ns}$ & $* * *$ & $\mathrm{~ns}$ \\
Shell width & $\mathrm{r}$ & 0.991 & 0.225 & 0.763 & 0.306 \\
& $P$ & $* * *$ & $\mathrm{~ns}$ & $* *$ & $\mathrm{~ns}$ \\
Number live & $\mathrm{r}$ & 0.379 & - & -0.174 & 0.172 \\
& $P$ & $\mathrm{~ns}$ & - & $\mathrm{ns}$ & $\mathrm{ns}$ \\
Seed length & $\mathrm{r}$ & 0.882 & 0.364 & - & - \\
& $P$ & $* * *$ & $\mathrm{~ns}$ & - & - \\
Spat area & $\mathrm{r}$ & 0.246 & 0.392 & - & - \\
& $P$ & $\mathrm{~ns}$ & $\mathrm{~ns}$ & - & - \\
\hline \multirow{5}{*}{ York River } & & Length & Live & Leed & Spat \\
\hline Shell length & $\mathrm{r}$ & - & - & - & Area \\
& $P$ & - & Entire site destroyed by & - \\
& & & Hurricane Isabel & \\
Number live & $\mathrm{r}$ & 0.176 & - & - & - \\
& $P$ & $\mathrm{~ns}$ & - & - & - \\
Seed length & $\mathrm{r}$ & 0.867 & 0.26 & - & - \\
& $P$ & $* * *$ & $\mathrm{~ns}$ & - & - \\
Spat area & $\mathrm{r}$ & 0.266 & 0.589 & - & - \\
& $P$ & $\mathrm{~ns}$ & $\mathrm{~ns}$ & - & - \\
\hline
\end{tabular}

$\mathrm{ns}=$ not significant, $*=P<0.05, * *=P<0.01, * * *=P<0.001$.

strains by increasing genome-wide heterozygosity. This is clearly not the case for most of the strains we tested. The two bestperforming stocks (KK and $\mathrm{SC}$ ) as well as the NJ strain show no advantages of outcrossing, and the two lines with the poorest performance show the strongest inbreeding depression.

Finally, there is evidence, at least at the level of strain-means we examined here, that growth performance in the field could be reasonably well predicted by measurements taken at an early stage in the culture process. Measurements collected on same-age spat when they were transferred from the upwelling system to nursery bags were essentially uncorrelated with size at the end of one or two growing seasons, a result that agrees with the findings of Hilbish et al. (1993) who found no significant genetic correlation between early larval growth (0-10 days) and shell length at 9 mo of age. However, the significant correlation between the shell length of seed when it was removed from the spat bags and planted into the field plots and adult characters indicate that seed size at a specific age may be a useful predictor of subsequent growth. This implies that the identification of superior seed for planting in the field could potentially be accomplished based on measurements taken under nursery conditions in commercial farms. Also, in the context of a selective breeding effort, it may be possible to identify and cull the most inferior genotypes based on measurements of juveniles, eliminating a great deal of the labor required to rear all of the animals being tested to harvestable size for evaluation.

Further study is required. Especially interesting would be an assessment of the levels of allelic richness and heterozygosity of both the parents and the progeny and an evaluation of whether these change over time as a consequence of selective mortality of more homozygous progeny. In addition, studies of more advanced 
hybrid generations are necessary to identify the genetic mechanisms underlying the phenotypic effects we detected.

\section{Mandatory USDA-ARS Disclaimer Statement}

Any use of trade, firm or corporation names in this publication is for the information and convenience of the reader. Such use does not constitute an official endorsement or approval by the United States Department of Agriculture or the Agricultural Research Service of any product or service to the exclusion of others that may be suitable.

\section{ACKNOWLEDGMENTS}

The authors thank Nate Geyerhahn, Tim Rapine, George Hall, and Ryan Gill for their tireless work in the hatchery and in the field, as well as Cherrystone Aquafarms, J. C. Walker Brothers, Middle Penninsula Aquaculture, and Tommy's Seafood for providing space at their farms for this experiment. This research was supported by the Commonwealth of Virginia through funding of the Aquaculture Genetics and Breeding Technology Center at the Virginia Institute of Marine Science and a grant from NOAAVirginia Sea Grant to Camara, Reece, and Carnegie.

\section{LITERATURE CITED}

Anonymous. 2000. 1998. Census of Aquaculture (http://www.nass usda.gov/census/census97/aquaculture/aquaculture.htm).

Carlsson, J., C.L. Morrison \& K.S. Reece. A wild and aquaculture population of the eastern oyster compared using microsatellites. Journal of Heredity. In review.

Chanley, P. E. 1960. Inheritance of shell markings and growth in the hard clam, (Venus mercenaria). Proceedings of the National Shellfish Association 50:163-169.

Dillon, R. T. \& J. J. Manzi. 1993. Managing bivalve broodstocks. World Aquaculture 24:47-53.

Ernande, B., P. Boudry, J. Clobert \& J. Haure. 2004. Plasticity in resource allocation based life history traits in the Pacific oyster, Crassostrea gigas. I. Spatial variation in food abundance. J. Evol. Biol. 17:342-356.

Evans, F., S. Matson, J. Brake \& C. Langdon. 2004. The effects of inbreeding on performance traits of adult Pacific oysters (Crassostrea gigas). Aquaculture 230:89-98.

Falconer, D. S. \& T. F. C. Mackay. 1996. An introduction to quantitative genetics. Addison Wesley Longman Limited, Essex, England, XV + 464 pp.

Ford, S. E., J. N. Kraeuter, R. D. Barber \& G. Mathis. 2002. Aquacultureassociated factors in QPX disease of hardclams: density and seed source. Aquaculture 208:23-38.

Gallivan, T. \& S. K. Allen, Jr. 2000. Clam Strain Registry. 72, Gloucester Point, VA.

Hadley, N., R. T. Dillon \& J. J. Manzi. 1991. Realized heritability of growth rate in the hard clam Mercenaria mercenaria. Aquaculture 93:109-119.

Hadley, N., J. J. Manzi, A. G. Eversole, R. T. Dillon, C. E. Battey \& N. M. Peacock. 1997. A manual for the culture of the hard clam Mercenaria spp. in South Carolina. 365, Sea Grant Consortium, South Carolina Marine Resources Center, Charleston, South Carolina.

Hadley, N. H. 1993. Effects of hard clam hatchery management practices on productivity and on broodstock quality. World Aquaculture 24:30 31.

Hare, M. P., S. K. Allen, P. Bloomer, M. D. Camara, R. B. Carnegie, J. Murfree, M. Luckenbach, D. Meritt, C. Morrison, K. Paynter, K. S. Reece \& C. G. Rose. 2006. A genetic test for recruitment enhancement in Chesapeake Bay oysters, Crassostrea virginica, after population supplementation with a disease tolerant strain.

Hedgecock, D., G. Li \& M.-L. Voigt. 2004. Mapping heterosis QTL in the Pacific oyster Crassostrea gigas. http://www.intl-pag.org/12/abstracts/ W06_PAG12_19.htm.

Hedgecock, D., D. J. McGoldrick, D. T. Manahan, J. Vavra, N. Appelmans \& B. L. Bayne. 1996. Quantitative and molecular genetic analyses of heterosis in bivalve molluscs. J. Exp. Mar. Biol. Ecol. 203:49-59.

Hedgecock, D. \& F. L. Sly. 1990. Genetic drift and effective population sizes of hatchery-propagated stocks of the Pacific oyster Crassostrea gigas. Aquaculture 88:21-38.

Hilbish, T. J. 2001. Genetics of hard clams, Mercenaria mercenaria. In: J. N. Kraeuter \& M. Castagna, editors. Biology of the hard clam. Developments in Aquaculture and Fisheries Science. Amsterdam: Elsevier. pp. 261-280.

Hilbish, T. J., E. P. Winn \& P. D. Rawson. 1993. Genetic variation and covariation during larval and juvenile growth in Mercenaria mercenaria. Mar. Biol. 115:97-104.

Langdon, C., F. Evans, D. Jacobson \& M. Blouin. 2003. Yields of cultured Pacific oysters Crassostrea gigas Thunberg improved after one generation of selection. Aquaculture 220:227-244.

Lynch, M. \& B. Walsh. 1998. Genetics and analysis of quantitative traits. Sinauer Massachusetts, USA: Associates Inc., Sunderland. XIII + 980 pp.

Lynch, M. \& B. Walsh. 2000. Evolution and Selection of Quantitative Traits Vol. 2. http://nitro.biosci.arizona.edu/zbook/volume_2/ vol2.html.

Newkirk, G. F. 1978a. A discussion of possible sources of inbreeding in hatchery stock and associated problems. Proceedings of the World Aquaculture Society 9:93-100.

Newkirk, G. F. 1978b. Interaction of genotype and salinity in larvae of the oyster Crassostrea virginica. Mar. Biol. 48:227-234.

Ragone Calvo, L. \& E. M. Burreson. 2002. QPX susceptibility in hard clams varies with geographic origin of brood stock, Virginia Institute of Marine Science, Gloucester Point, VA. Virginia Sea Grant Marine Resource Advisory No. 74 VSG-02-18.

Ragone Calvo, L. M., E. M. Burreson, S. E. Ford, J. N. Kraeuter, D. F. Leavitt \& R. Smolowitz. 2003. Influence of host genetic origin and geographic location on QPX disease in hard clams, Mercenaria mercenaria., Virginia Institute of Marine Science, Gloucester Point, VA. Final Report to NOAA, NMFS, Saltonstall-Kennedy Program Grant Number NA96FD0075.

Rawson, P. D. \& T. J. Hilbish. 1990. Heritability of juvenile growth for the hard clam Mercenaria mercenaria. Mar. Biol. 105:429-436.

Rawson, P. D. \& T. J. Hilbish. 1991. Genotype-environment interaction for juvenile growth in the hard clam Mercenaria mercenaria (L.). Evolution Int. J. Org. Evolution 45:1924-1935.

SAS. I., 2000. SAS OnlineDoc, Version 8, http://v8doc.sas.com/sashtml/. Cary, NC: SAS Institute Inc.

Taris, N., B. Ernande, H. McCombie \& P. Boudry. 2006. Phenotypic and genetic consequences of size selection at the larval stage in the Pacific oyster (Crassostrea gigas). J. Exp. Mar. Biol. Ecol. 333:147-158.

Zhang, Q., S. K. Allen \& K. S. Reece. 2005. Genetic variation in wild and hatchery stocks of suminoe oyster (Crassostrea ariakensis) assessed by PCR-RFLP and microsatellite markers. Mar. Biotechnol. 7:588-599. 